\title{
Manfaat Interaksi Teman Sebaya Terhadap Perilaku Sosial Anak Usia Dini Di Ra Muslimat Nu 007 Gandu 1 Mlarak Kabupaten Ponorogo Provinsi Jawa Timur
}

\author{
Nuning Farida ${ }^{1}$, Devi Anggi Friani ${ }^{2}$ \\ ${ }^{1}$ Dosen, Universitas Doktor Nugroho Magetan, Jln. Sendang Kamal No.50, Magetan, 63392 \\ E-mail: nuningfarida@udn.ac.id \\ ${ }^{2}$ Dosen, Universitas Doktor Nugroho Magetan, Jln. Sendang Kamal No.50, Magetan, 63392 \\ E-mail: nuningfarida@udn.ac.id
}

\begin{abstract}
To create a good social environment for children, the necessary peer, because peers have an important role creating a social environment that supports the development of a child's social behavior. In life there are inter-peer social process in which a process of mutual influence and be influenced. This research is a qualitative descriptive study, the data obtained by observation, interview, and documentation. Technique authenticity of data using triangulation techniques. Qualitative data analysis conducted interactivity and runs continuously until complete, so that the data is already saturated. Activity in the data analysis that is data reduction, data display, and conclusion drawing / verification ". From the research results can be known early childhood social behavior in NU's RA 007 Gandu 1 Mlarak Ponorogo well developed which can be evidenced by the attitude of helping each other, appreciate each other, working together, were able to distinguish between good and bad and incapable of being polite. Peer interaction is also developing well. The benefits of peer interaction on the social behavior of early childhood, among others, children can learn to respect others, to have an attitude of responsibility, learn to work together, sharing and caring about the condition of another friend. They learn to empathize and begin to learn to help a friend in trouble. able to distinguish between good and bad and incapable of being polite. Peer interaction is also developing well. The benefits of peer interaction on the social behavior of early childhood, among others, children can learn to respect others, to have an attitude of responsibility, learn to work together, sharing and caring about the condition of another friend. They learn to empathize and begin to learn to help a friend in trouble. able to distinguish between good and bad and incapable of being polite. Peer interaction is also developing well. The benefits of peer interaction on the social behavior of early childhood, among others, children can learn to respect others, to have an attitude of responsibility, learn to work together, sharing and caring about the condition of another friend. They learn to empathize and begin to learn to help a friend in trouble.
\end{abstract}

Keywords - : peer interaction; social behavior; early childhood.

\section{PENDAHULUAN}

Usia dini adalah usia emas atau golden age, dimana usia emas merupakan masa penting pembentukan karakter anak. Stimulasi dalam masa emas ini sangat diperlukan agar anak memiliki perkembangan optimal. Stimulasi tumbuh kembang anak dapat dilakukan melalui interaksi dengan lingkungan keluarga maupun lingkungan sosial sekitarnya. Setiap saat anak harus mendapatkan stimulasi secara terus menerus. Kurang stimulasi dapat menyebabkan penyimpangan tumbuh kembang anak bahkan gangguan menetap. Stimulasi perkembangan anak harus di berikan dalam setiap aspek perkembangannya , yaitu meliputi perkembangan kognitif, motorik, kemampuan bicara dan bahasa, serta perkembangan sosial dan emosionalnya.

Perkembangan anak sangat penting untuk pertumbuhan anak ketika dewasa, terutama perkembangan sosial. Perkembangan sosial dibutuhkan anak usia dini untuk belajar mengetahui dan memahami lingkungan. Kemampuan interaksi sosial merupakan pondasi perkembangan kemampuan anak berinteraksi dengan lingkungan secara lebih luas. Kurangnya kemampuan sosial anak seperti diharapkan lingkungan menyebabkan anak terkucilkan dari lingkungan, anak tidak percaya diri sehingga menyebabkan anak akan mengalami kendala dalam perkembangan sosialnya. Sebagai makhluk sosial selalu berinteraksi dengan orang lain maka keterampilan sosial yang baik harus ditanamkan pada anak sejak dini. Dengan ini diharapkan agar anak tetap bisa menjalani kehidupan sosial dalam masyarakat.

Interaksi sosial bisa dikembangkan kepada anak melalui berbagai cara diantaranya memberikan waktu cukup kepada anak untuk bermain atau bercanda dengan teman sebaya, memberikan tugas dan tanggungjawab sesuai perkembangan anak dan sebagainya. Kehidupan sosial anak yang baik akan membantu memudahkan anak dalam memenuhi tugas-tugas perkembangan berikutnya sehingga anak dapat berkembang secara normal dan sehat saat dewasa nanti.

Interaksi dengan teman sebaya mampu menciptakan kehidupan sosial yang baik untuk perkembangan anak. Hal ini dikarenakan dalam kehidupan teman sebaya didalamnya terjadi proses sosial dimana terjadi proses saling mempengaruhi dan dipengaruhi diantara mereka. Ini menyebabkan anak menjadi lebih pandai, kreatif, bisa belajar bekerja sama, belajar tenggang rasa serta yang terpenting belajar mengembangkan kemampuan sosial yang dimilikinya. 
Pergaulan antar teman sebaya pada dasarnya tidak hanya bermain saja seperti yang kita lihat pada umumnya namun juga merupakan satu cara bergaul. Dalam bermain mereka juga bergaul dan mereka memulainya dengan berkenalan, berunding untuk memilih permainan dan peralatannya, bergantian, serta mempertahankan hak miliknya. Bermain dengan teman sebaya juga bisa membantu anak untuk hidup lebih mandiri. Anak mudah belajar memecahkan masalah dihadapi selama proses bermain dan akan membentuk sikap dan perilaku anak yang akan menjadi bekal dalam interaksi ketika mereka kelak dewasa.

Berdasarkan latar belakang tersebut maka Peneliti ingin melakukan sebuah analisis perilaku sosial anak-anak yang hidup bersama dengan teman sebayanya dengan sebuah judul "Manfaat Interaksi Teman Sebaya terhadap Perilaku Sosial Anak Usia Dini di RA Muslimat NU 007 Gandu 1 Mlarak Kabupaten Ponorogo Provinsi Jawa Timur".

Manfaat dari penelitian ini di harapkan dapat memberikan pengetahuan yang mendalam dan tentunya komprehensip adanya pemanfaatan interaksi teman sebaya dengan perilaku sosial anak usia dini, Dapat diperoleh sebuah pendekatan Ilmu Sosial pada studi pemanfaatan interaksi teman sebaya dengan perilaku sosial anak usia dini, Memberikan sumbangan pemikiran serta pengetahuan yang berkaitan dengan Sosial khususnya dalam perilaku sosial anak usia dini dengan pemanfaatan interaksi teman sebaya terhadap perilaku sosial anak usia dini.

\section{KAJIAN PUSTAKA}

\section{A. Anak Usia Dini}

Anak usia dini itu sendiri merupakan anak yang berkisar antara usia 0-6 tahun dengan keunikan masing-masing. Menurut Muhammad (2012: 9) Anak usia dini adalah anak yang berkisar anatar usia 0-6 tahun yang memiliki pertumbuhan dan perkembangan yang luar biasa sehingga memunculkan berbagai keunikan pada dirinya. Pada tahap inilah, masa yang tepat untuk menanamkan nilai-nilai kebaikan yang nantinya diharapkan dapat membentuk kepribadiannya.

Menurut Yamin dan Sanan (2013: 4) masa usia dini adalah masa yang sangat menentukan bagi perkembangan dan pertumbuhan anak selanjutnya karena merupakan masa peka dan masa emas dalam kehidupan anak. Hal ini mengisyaratkan bahwa semua pihak perlu memahami akan pentingnya masa usia dini untuk optimalisasi pertumbuhan dan perkembangan.

Dari beberapa pendapat para ahli diatas dapat disimpulkan bahwa anak usia dini adalah kelompok anak dengan rentang usia 0-6 tahun yang berada dalam proses pertumbuhan dan perkembangan bersifat unik.

Usia lahir sampai dengan memasuki pendidikan dasar merupakan masa keemasan sekaligus masa kritis dalam tahapan kehidupan manusia, yang akan menentukan perkembangan anak selanjutnya. Masa ini merupakan masa yang tepat untuk meletakkan dasar-dasar pengembangan kemampuan fisik, bahasa, sosial-emosional, konsep diri, seni moral, dan nilai agama Sehingga upaya pengembangan seluruh potensi anak usia dini harus dimulai agar pertumbuhan dan perkembangan anak tercapai optimal.

Menurut Aden (2011: 57) pendidikan anak usia dini (PAUD) adalah jenjang pendidikan sebelum jenjang pendidikan dasar yang merupakan suatu upaya pembinaan yang ditujukan bagi anak sejak lahir sampai dengan usia enam tahun yang dilakukan melalui pemberian rangsangan pendidikan untuk membantu pertumbuhan dan perkembangan jasmani dan rohani agar anak memiliki kesiapan dalam memasuki pendidikan lebih lanjut, yang diselenggarakan pada jalur formal, nonformal, dan informal.

\section{B. Perilaku Sosial Anak Usia Dini}

Pada tahun pertama perilaku sosial yang diterapkan pada anak usia dini penting untuk penyesuaian sosial yang memungkinkan anak dapat bergaul dengan teman-temannya. Hal ini dikarenakan pada periode ini merupakan pembentukan sikap dan pola perilaku sosial. Pola perilaku sosial yang perlu dikembangkan kepada anak usia dini yaitu meliputi menghargai teman, baik menghargai milik, pendapat, hasil karya teman, atau kondisi-kondisi yang ada pada teman misalnya anak tidak mengejek atau mengisolasi anak lain yang memiliki kekurangan pada anggota tubuhnya. Pengembangan perilaku social juga bisa diarahkan untuk mengajarkan anak mau membantu kepada orang lain, tidak egois, sikap kebersamaan, sikap kesederhanaan, dan kemandirian.

Menurut Hurlock dalam Susanto (2011: 139), secara spesifik mengklasifikasikan pola perilaku sosial pada anak usia dini ini ke dalam pola-pola perilaku sebagai berikut :

a. Meniru, yaitu agar sama dengan kelompok, anak meniru sikap dan perilaku orang yang sangat ia kagumi. Anak mampu meniru perilaku guru yang diperagakan sesuai dengan tema pembelajaran.

b. Persaingan, yaitu keinginan untuk mengungguli dan mengalahkan orang lain. Persaingan ini biasanya sudah tampak pada usia empat tahun. Anak bersaing dengan teman untuk meraih prestasi seperti berlomba-lomba dalam memperoleh juara dalam suatu permainan, menunjukkan antusiasme dalam mengerjakan sesuatu.

c. Kerja sama. Mulai usia tahun ketiga akhir, anak mulai bermain secara bersama dan kooperatif, serta kegiatan kelompok mulai berkembang dan meningkat baik dalam frekuensi maupun lamanya berlangsung, bersama dengan meningkatnya kesempatan untuk bermain dengan anak lain.

d. Simpati. Karena simpati membutuhkan pengertian tentang perasaan- perasaan dan emosi orang lain, maka hal ini hanya kadang-kadang timbul sebelum tiga tahun. Semakin banyak kontak bermain, semakin cepat simpati akan berkembang.

e. Empati. Seperti halnya simpati, empati membutuhkan pengertian tentang perasaan dan emosi orang lain, tetapi disamping itu juga membutuhkan kemampuan untuk membayangkan diri sendiri di temapt orang lain. Relative hanya sedikit anak yang dapat melakukan hal ini sampai awal masa kanak-kanak akhir. 
f. Dukungan Sosial. Menjelang berakhirnya awal masa kanak-kanak dukungan dari teman - teman menjadi lebih penting daripada persetujuan orang - orang dewasa.

g. Membagi. Anak mengetahui bahwa salah satu cara untuk memperoleh persetujuan sosial ialah membagi miliknya, terutama mainan untuk anak- anak lainnya. Pada momen-momen tertentu, anak juga rela membagi makanan kepada anak lain dalam rangka mempertebal tali pertemanan mereka dan menunjukkan identitas keakraban antar mereka.

h. Perilaku akrab. Anak memberikan rasa kasih saying kepada guru dan teman. Bentuk dari perilaku akrab diperlihatkan dengan canda gurau dan tawa riang diantara mereka. Kepada guru, mereka memperlakukan sebagaimana layaknya pada orang tua mereka sendiri, memeluk, merangkul, digendong, memegang tangan sang guru, dan banyak bertanya.

Terdapat beberapa alasan mengapa anak perlu mempelajari berbagai perilaku sosial. Sedikitnya ada empat alasan sebagaimana yang dikemukakan oleh sujiono dalam Suyadi (2011: 140) sebagai berikut :

a. Agar anak dapat belajar bertingkah laku yang dapat diterima lingkungannya.

b. Agar anak dapat memainkan peranan sosial yang bisa doterima kelompoknya, misalnya berperan sebagai laki-laki dan perempuan.

c. Agar anak dapat mengembangkan sikap sosial yang sehat terhadap lingkungannya yang merupakan modal penting untuk sukses dalam kehidupan sosialnya kelak.

d. Agar anak mampu menyesuaikan dirinya dengan baik, sehingga lingkungannya pun dapat menerimanya dengan senang hati. Menurut Beaty dalam Susanto (2011:137), menyatakan bahwa perkembangan sosial anak berkaitan dengan perilaku prososial dan bermain sosialnya. Aspek perilaku sosial meliputi :

a. Empati, yaitu menunjukkan perhatian kepada orang lain yang kesusahan atau menceritakan perasaan orang lain yang mengalami konflik.

b. Kemurahan Hati, yaitu berbagi sesuatu dengan yang lain atau memberikan barang miliknya.

c. Kerja Sama, yaitu bergantian menggunakan barang, melakukan sesuatu dengan gembira.

d. Kepedulian, yaitu membantu orang lain yang sedang membutuhkan bantuan.

Menurut Susanto (2011:148) anak-anak usia dini biasanya mudah bersosialisasi dengan orang sekitarnya. Umumnya anak usia ini memiliki satu atau dua sahabat, tetapi sahabat ini mudah berganti. Mereka umumnya mudah dan cepat menyesuaikan diri secara sosial. Sahabat yang dipilih biasanya yang memiliki jenis kelamin yang sama, kemudian berkembang kepada jenis kelamin yang berbeda. Kelompok bermain anak usia ini cenderung kecil dan tidak terorganisasi secara baik, oleh karena itu kelompok ini cepat berganti. Beberapa tingkah laku sosial anak usia dini ketika mereka sedang bermain bebas sebagai berikut :

a. Tingkah laku unoccupied" Anak tidak bermain dengan sesungguhnya. Dia mungkin berdiri di sekitar anak lain dan memandang temannya tanpa melakukan kegiatan apa pun.

b. Bermain soliter : Anak bermain sendiri dengan menggunakan alat permainan berbeda dengan apa yang dimainkan oleh teman yang ada di dekatnya. Mereka tidak berusaha untuk saling bicara.

c. Tingkah laku onlooker: Anak menghabiskan waktu dengan mengamati. Kadang memberi komentar tentang apa yang dimainkan anak lain, tetapi tidak berusaha untuk bermain bersama.

d. Bermain parallel : Anak bermain denga saling berdekatan, tetapi tidak sepenuhnya bermain bersama dengan anak yang lain. Mereka menggunakan alat mainan yang sama, berdekatan tetapi dengan cara yang tidak saling bergantung.

e. Bermain asosiatif : Anak bermain dengan anak lain tetapi tanpa organisasi. Tidak ada peran tertentu, masing-masing anak bermain dengan caranya sendiri-sendiri.

f. Bermain kooperatif :Anak bermain dalam kelompok di mana ada organisasi, ada pimpinannya. Masing-masing anak melakukan kegiatan bermain dalam kegiatan bersama, misalnya perang-perangan, sekolah- sekolahan, dan lain-lain. Sejalan dengan perkembangan kognitif anak.

\section{Interaksi Teman Sebaya}

Teman sebaya diartikan sebagai kawan, sahabat atau orang yang sama-sama bekerja atau berbuat. Menurut Mu'tadin (2002:1) menjelaskan bahwa teman sebaya adalah kelompok orang-orang yang seumur dan mempunyai kelompok sosial yang sama, seperti teman sekolah atau teman sekerja. Teman sebaya (peer) sebagai sebuah kelompok sosial sering didefinisikan sebagai semua orang yang memiliki kesamaan ciri-ciri seperti kesamaan tingkat usia.

Interaksi sosial dengan teman sebaya adalah proses timbal balik antara individu dengan kelompok sosialnya yang seusia, yang di dalamnya mencakup adanya keterbukaan dalam kelompok, kerjasama dalam kelompok dan frekuensi hubungan individu dengan kelompok, yang mana interaksi teman sebaya tersebut dapat mengajarkan kepada anak tentang cara bergaul di lingkungan baik dalam lingkungan keluarga, sekolah maupun masyarakat (Eka Setiawati dan Suparno dalam Regina, 2010:57).

Anak-anak memerlukan interaksi yang positif dengan teman-teman sebaya mereka. Teman sebaya adalah anak-anak yang tingkat usia dan kematangannya kurang lebih sama. John W Santrock (2007: 55) mengatakan bahwa kawan-kawan sebaya adalah anak-anak atau remaja yang memiliki usia atau tingkat kematangan yang kurang lebih sama.

Anak-anak memerlukan interaksi yang positif dengan teman-teman sebaya mereka. Kelompok teman sebaya akan terbentuk dengan sendirinya pada anak-anak yang tinggal berdekatan rumah atau pergi ke sekolah bersama-sama. Hal ini didukung pendapat Santrock (2008:128) Kelompok teman sebaya akan terbentuk dengan sendirinya pada anak-anak yang tinggal berdekatan rumah atau pergi ke sekolah bersama-sama. 
Dari beberapa pengertian diatas, maka dapat disimpulkan bahwa teman sebaya adalah hubungan antar anak dengan tingkat usia yang sama serta melibatkan keakraban yang relatif besar dalam suatu kelompoknya.

Ditinjau dari sifat organisasinya kelompok sebaya dapat dibedakan menjadi:

a. Kelompok sebaya yang bersifat informal. Kelompok sebaya ini dibentuk, diatur, dan dipimpin oleh anak itu sendiri misalnya, kelompok permainan, gang, dan lain-lain. Di dalam kelompok ini tidak ada bimbingan dan partisipasi orang dewasa.

b. Kelompok sebaya yang bersifat formal. didalam kelompok ini ada bimbingan, partisipasi atau pengarahan orang dewasa. Apabila bimbingan dan pengarahan diberikan secara bijaksana maka kelompok sebaya ini dapat menjadi wahana proses sosialisasi nilai-nilai dan norma yang terdapat dalam masyarakat. Yang termasuk dalam kelompok sebaya ini misalnya, kepramukaan, klub, perkumpulan pemuda dan organisasi lainnya.

Anak usia dini memiliki kebutuhan yang kuat untuk disukai dan diterima kawan sebaya atau kelompok. Sebagai akibatnya, mereka akan merasa senang apabila diterima dan sebaliknya akan merasa sangat tertekan dan cemas apabila dikeluarkan dan diremehkan oleh kawan-kawan sebayanya. Bagi remaja, pandangan kawan-kawan terhadap dirinya merupakan hal yang paling penting. Santrock (2007: 55) mengemukakan fungsi terpenting dari kelompok teman sebaya adalah:

a. Sebagai sumber informasi mengenai dunia di luar keluarga.

b. Memperoleh umpan balik mengenai kemampuannya dari kelompok teman sebaya

c. Mempelajari bahwa apa yang mereka lakukan itu lebih baik, sama baik, atau kurang baik, dibandingkan remaja lainnya.

Piaget dan Sullivan (dalam Suyadi, 2010: 57) menekankan bahwa melalui interaksi dengan teman-teman sebaya, anak-anak dan remaja mempelajari modus relasi yang timbal balik secara simetris. Anak-anak mengeksplorasi prinsip-prinsip kesetaraan dan keadilan melalui pengalaman mereka ketika menghadapi perbedaan pendapat dengan teman-teman sebaya. Sebaliknya, terdapat sejumlah ahli teori yang menekankan pengaruh negatif dari teman-teman sebaya bagi perkembangan anak dan remaja. Bagi beberapa anak, pengalaman ditolak atau diabaikan dapat membuat mereka merasa kesepian dan bersikap bermusuhan. Hubungan yang baik di antara teman sebaya akan sangat membantu dalam perkembangan aspek sosial anak secara normal. Anak pendiam yang ditolak oleh teman sebayanya dalam pergaulan, dan merasa kesepian dalam kehidupannya berisiko menderita depresi. Anak-anak yang agresif terhadap teman sebaya berisiko pada berkembangnya sejumlah masalah yang bersifat negatif seperti kenakalan dan drop out dari sekolah.

Berdasarkan uraian tersebut maka dapat diketahui bahwa teman sebaya yang merupakan lingkungan sosial bagi anak, mempunyai peranan yang cukup penting bagi perkembangan kepribadiannya. Teman sebaya memberikan sebuah dunia baru tempat anak bersosialisasi dalam suasana yang mereka ciptakan sendiri. Teman sebaya adalah kelompok baru yang memiliki ciri, norma dan kebiasaan yang jauh berbeda dengan apa yang ada di lingkungan keluarganya, dimana kelompok teman sebaya ini merupakan lingkungan sosial yang pertama dimana anak bisa belajar untuk hidup bersama dengan orang lain yang bukan merupakan anggota keluarganya. Disini anak dituntut untuk memiliki kemampuan baru dalam menyesuaikan diri dan dapat dijadikan dasar dalam interaksi sosial yang lebih besar.

Dukungan sosial yang diberikan individu kepada individu yang lain pada prinsipnya terdiri dari empat macam yang sangat luas (Yanita dan Zamralita, 2001:38):

a. Dukungan Emosional : Meliputi ekspresi dari empati penuh perhatia kepada orang yang bersangkutan.

b. Pernghargaan : ekspresi dari penghargaan secara positif kepada individu memberikan perbandingan positif antar individu untuk membangun perasaan yag lebih baik terhadap dirinya.

c. Instrumental : meliputi bantuan langsung seperti ketika seseorang membantu mereka menyelesaikan tugas-tugasnya saat merekadalam kondisi stres.

d. Dukungan Informatif : Meliputi pemberian informasi, nasehat, sugesti, ataupun umpan balik mengenai apa yang sebaiknya dilakukan oleh mereka.

Lebih lanjut lagi secara lebih rinci Kelly dan Hansen dalam Samsunuwiyati (2005: 220) menyebutkan 6 fungsi positif dari teman sebaya, yaitu:

a. Mengontrol impuls-impuls agresif.

b. Memperoleh dorongan emosional dan sosial serta menjadi lebih independen. Teman-teman dan kelompok teman sebaya memberikan dorongan untuk mengambil peran dan tanggung jawab baru mereka.

c. Meningkatkan keterampilan-keterampilan sosial, mengembangkan kemampuan penalaran, dan belajar untuk mengekspresikan perasaan-perasaan dengan cara-cara yang lebih matang.

d. Mengembangkan sikap terhadap seksualitas dan tingkah laku peran jenis kelamin.

e. Memperkuat penyesuaian moral dan nilai-nilai.

f. Meningkatkan harga diri (self-esteem). Menjadi orang yang disukai oleh sejumlah besar teman-teman sebayanya membuat remaja merasa enak atau senang senang tentang dirinya.

Berdasarkan uraian tersebut maka dapat diketahui bahwa teman sebaya sebagai lingkungan sosial bagi anak mempunyai peranan yang cukup penting bagi perkembangan kepribadiannya. Teman sebaya memberikan sebuah dunia tempat para anak melakukan sosialisasi dalam suasana yang mereka ciptakan sendiri. Teman sebaya adalah kelompok baru yang memiliki ciri, norma dan kebiasaan yang jauh berbeda dengan apa yang ada di lingkungan keluarganya, dimana kelompok teman sebaya ini merupakan lingkungan sosial yang pertama dimana anak bisa belajar untuk hidup bersama dengan orang lain yang bukan merupakan anggota keluarganya. Disinilah anak dituntut untuk memiliki kemampuan baru dalam menyesuaikan diri dan dapat dijadikan dasar dalam interaksi sosial yang lebih besar. 


\section{III.METODE PENELITIAN}

Lokasi penelitian di RA Muslimat NU 007 Gandu 1 Mlarak Kabupaten Ponorogo Provinsi Jawa Timur. Obyek penelitiannya adalah seluruh siswa RA Muslimat NU 007 Gandu 1 Mlarak Kabupaten Ponorogo Provinsi Jawa Timur.

Teknik pengumpulan data merupakan langkah yang paling strategis dalam penelitian, karena tujuan utama penelitian ini adalah mendapatkan data. Dalam penelitian deskriptif kualitatif data diperoleh dengan terjun secara langsung ke lapangan untuk melakukan pengamatan (observasi), indepth interview (wawancara mendalam), dan studi dokumentasi.

Observasi dilakukan untuk memperoleh data berupa gambaran yang ada di lapangan baik dalam bentuk sikap, tindakan, pembicaraan, interaksi interpersonal dan lain-lain. Untuk itu observasi dilaksanakan dalam bentuk pengamatan yang tidak berstruktur, dalam arti dilakukan dengan mengikuti alur situasi dan kondisi wilayah pengamatan, mengalir dan larut dalam aktivitas yang terjadi di lapangan

Wawancara dilakukan untuk mendapatkan informasi yang tidak dapat diperoleh melalui observasi atau teknik pengumpulan data lainnya. Hal ini lebih disebabkan karena keterbatasan peneliti untuk melakukan pengamatan secara keseluruhan. Di samping itu, tidak semua data dapat diperoleh melalui pengamatan, sehingga mengharuskan peneliti untuk melakukan wawancara kepada responden yang dimaksudkan. Dalam hal ini peneliti melakukan wawancara kepada pihak yang terkait dengan masalah yang diteliti yaitu guru dan siswa.

Penggalian informasi melalui dokumen-dokumen penting seperti riwayat keberadaan masyarakat di wilayah RA Muslimat NU 007 Gandu 1 Mlarak Ponorogo, data-data pada kegiatan sosial di lingkungan masyarakat yang kompleks dan dinamis, dan sebagainya. Lewat metode ini pula, peneliti berharap akan dapat melihat data dari dimensi yang lainnya selain yang diperoleh dari pengamatan dan wawancara mendalam.

Teknik keabsahan data yang digunakan dalam penelitian ini adalah dengan teknik triangulasi. Menurut Sugiyono (2015:372) "triangulasi dalam pengujian kredibilitas ini diartikan sebagai pengecekan data dari berbagai sumber dengan berbagai cara, dan berbagai waktu.

Analisis data dalam penelitian kualitatif dilakukan sejak sebelum memasuki lapangan, selama di lapangan, dan setelah selesai melakukan kegiatan penelitian di lapangan. Hal ini sesuai dengan pendapat Nasution (dalam Sugiyono, 2015:336) yang menyatakan bahwa "analisis telah mulai sejak merumuskan dan menjelaskan masalah, sebelum terjun ke lapangan, dan berlangsung terus sampai penulisan hasil penelitian". Milles and Huberman (dalam Sugiyono, 2015:337) mengemukakan bahwa "aktivitas dalam analisis data kualitatif dilakukan secara interakif dan berlangsung secara terus menerus sampai tuntas, sehingga datanya sudah jenuh. Aktifitas dalam analisis data yaitu data reduction, data display, dan conclusion drawing/verification".

\section{IV.HASIL PENELITIAN DAN PEMBAHASAN}

\section{A. Perilaku sosial anak usia dini di RA Muslimat NU 007 Gandu 1 Mlarak Kabupaten Ponorogo Provinsi Jawa Timur}

Perilaku sosial anak merupakan pondasi dalam penyesuaian sosial dalam kehidupan bermasyarakat. Sebagai lingkungan sosial pertama yang di kenal anak, keluarga harus bisa mendidik perilaku sosial anak agar memiliki perkembangan sosial yang baik. Karena dengan berkembangnya perilaku sosial yang baik anak akan mampu bertingkah laku serta dapat memainkan peranan sosial yang bisa di terima di lingkungannya. Hal ini sesuai dengan pendapat Sujiono dalam Suyadi (2011:140) mengenai pentingnya mengembangkan perilaku sosial anak yaitu sebagai berikut:

a. Agar anak dapat belajar bertingkah laku yang dapat diterima lingkungannya.

b. Agar anak dapat memainkan peranan sosial yang bisa diterima kelompoknya, misalnya berperan sebagai laki-laki dan perempuan.

c. Agar anak dapat mengembangkan sikap sosial yang sehat terhadap lingkungannya yang merupakan modal penting untuk sukses dalam kehidupan sosialnya kelak.

d. Agar anak mampu menyesuaikan dirinya dengan baik, dan akibatnya lingkungannya pun dapat menerimanya dengan senang hati.

Dengan kemampuan perilaku sosial yang baik, anak akan lebih percaya diri dalam bergaul dan lebih mudah untuk mengembangkan potensi yang dimilikinya.

Berdasarkan hasil penelitian dapat diketahui bahwa perilaku sosial anak usia dini di RA Muslimat NU 007 Gandu 1 Mlarak Ponorogo tergolong baik. Hal ini dapat diketahui dari pergaulan antar siswa dalam kesehariannya. Dilihat dari hasil observasi, sebagian besar siswa sudah mampu menolong temannya yang mengalami kesulitan. Pada saat kegiatan pembelajaran, jika ada teman yang tidak membawa alat tulis, teman yang lain saling meminjami sehingga kegiatan pembelajaran tetap bisa berjalan lancar.

Siswa sudah mampu berbagi mainan dengan temannya. Pada saat jam istirahat mereka mampu bermain dengan baik dengan memanfaatkan media permainan yang tersedia di sekolah dengan tidak saling berebut dengan teman yang lain.

Selain itu siswa juga sudah mampu membedakan perbuatan yang baik dan buruk. Mereka tidak saling memukul ketika bermain, tidak berbicara kotor, membuang sampah pada tempatnya, dan selalu mengembalikan mainan pada tempatnya setelah mereka selesai bermain.

Dalam kegiatan kelompok, siswa sudah bisa belajar menghargai pendapat teman yang lain maupun hasil karya teman yang lain. Siswa juga mampu melaksanakan tugas-tugas yang diberikan oleh guru dengan baik. Jika ada temannya yang bertanya atau memberikan usulan, mereka menghargai dan tidak saling mencela pendapat yang diberikan. Pada saat ada tugas dari guru untuk 
mewarnai gambar, mereka bisa mengerjakan tugas itu dengan baik tanpa mengejek hasil teman yang lain yang mungkin menurutnya kurang bagus.

Dalam keseharian, mayoritas siswa sudah mampu berbicara dan bersikap sopan terhadap guru. Setiap datang dan pulang siswa bersalaman dengan guru dengan mencium tangan guru. Siswa juga tidak membantah apa yang diperintahkan oleh guru sehingga semua tugas terlaksana dengan lancar.

Siswa sudah terbiasa mengucapkan terima kasih apabila sudah diberikan sesuatu, baik diberi guru maupun teman yang lain. Kebiasaan tersebut sudah ditanamkan sejak awal mereka masuk ke sekolah .

Dengan demikian dapat ditarik suatu kesimpulan bahwa perilaku sosial anak usia dini di RA Muslimat NU 007 Gandu 1 Mlarak Ponorogo berkembang baik yang dapat dibuktikan dengan adanya sikap saling menolong, saling menghargai, saling bekerja sama, mampu membedakan yang baik dan buruk serta mampu bersikap sopan santun.

\section{B. Interaksi teman sebaya di RA Muslimat NU 007 Gandu 1 Mlarak Kabupaten Ponorogo Provinsi Jawa Timur}

Teman sebaya memiliki peranan besar dalam membentuk perilaku sosial anak. Hal ini didukung pendapat Susanto (2011:148) bahwa anak-anak usia dini biasanya mudah bersosialisasi dengan orang sekitarnya. Umumnya anak usia ini memiliki satu atau dua sahabat, tetapi sahabat ini mudah berganti. Mereka umumnya mudah dan cepat menyesuaikan diri secara sosial. Sahabat yang dipilih biasanya yang memiliki jenis kelamin yang sama, kemudian berkembang kepada jenis kelamin yang berbeda. Kelompok bermain anak usia ini cenderung kecil dan tidak terorganisasi secara baik, oleh karena itu kelompok ini cepat berganti.

Berdasarkan hasil observasi dan wawancara yang dilakukan, dapat diketahui bahwa interaksi dengan teman sebaya anakanak di RA Muslimat NU 007 Gandu 1 Mlarak Ponorogo sudah terjadi sejak awal mereka masuk sekolah. Hal ini dikarenakan mayoritas mereka berasal dari desa yang sama sehingga lebih memudahkan mereka untuk berinteraksi.

Selain dengan teman yang sudah dikenal sebelumnya, mereka juga melakukan interaksi dengan teman sebayanya di kelas. Mereka bermain bersama sehingga dapat mengenal satu sama lain. Mereka saling bercerita tentang dunianya sehingga timbul interaksi yang aktif diantara mereka. Selain bermain bersama mereka juga berkelompok untuk mengerjakan tugas yang diberikan oleh guru.

Dari hasil observasi, mayoritas seluruh siswa kelas B di RA Muslimat NU 007 Gandu 1 Mlarak Ponorogo sudah mampu berinteraksi dengan baik dengan teman sebayanya, namun ada satu anak yang tidak bisa berinteraksi dengan baik dengan teman sebayanya. Berdasarkan hasil wawancara dengan guru di TK B RA Muslimat NU 007 Gandu 1 Mlarak Ponorogo, anak tersebut memiliki riwayat keluarga yang broken home sehingga anak tersebut cenderung lebih suka menyendiri dibandingkan harus berinteraksi dengan teman sebayanya.

Salah satu upaya untuk mengatasi hal itu maka guru memberikan perhatian khusus kepada anak tersebut setelah anak-anak yang lain selesai. Guru melakukan pendekatan agar anak tersebut terbuka dan memiliki rasa percaya diri tinggi sehingga mampu berinteraksi dengan temannya yang lain.

Dengan demikian dapat disimpulkan bahwa interaksi teman sebaya di RA Muslimat NU 007 Gandu 1 Mlarak Ponorogo berkembang dengan baik, anak sudah mampu berinteraksi dengan baik, bersahabat dan bermain bersama temannya, meski ada salah satu anak yang kurang dalam interaksinya namun kini sudah mulai berkembang berkat berbagai pendekatan yang dilakukan guru.

\section{Manfaat interaksi teman sebaya terhadap perilaku sosial anak usia dini di RA Muslimat NU 007 Gandu 1 Mlarak Kabupaten Ponorogo Provinsi Jawa Timur}

Teman sebaya memiliki peranan yang cukup penting bagi perkembangan sosial dan kepribadian anak. Teman sebaya memberikan sebuah dunia tempat para anak melakukan sosialisasi dan interaksi dalam suasana yang mereka ciptakan sendiri. Dengan teman sebaya anak bersosialisasi dan menjalin keakraban, sehingga mampu meningkatkan hubungan dengan teman,serta anak mendapatkan rasa kebersamaan.

Anak bergabung dengan kelompok teman sebaya karena mereka beranggapan menjadi anggota kelompok akan menyenangkan dan menarik serta dapat memenuhi kebutuhan mereka atas hubungan dekat dan kebersamaan. Apabila anak tidak berinteraksi dengan yang lain maka anak akan menyendiri dan itu sangat tidak menyenangkan. Jika mereka mencari hubungan yang akrab dengan teman sekelas atau peduli akan kebaikan teman yang lain, mereka akan antusias terlibat dalam aktivitas di sekolah, baik itu dalam pergaulan maupun dalam menerima materi pelajaran.

Dengan berinteraksi dengan teman sebaya, anak dapat belajar untuk saling menghargai orang lain, memiliki sikap tanggung jawab, belajar bekerja sama, saling berbagi dan peduli terhadap kondisi teman yang lain. Mereka belajar untuk berempati dan mulai belajar membantu teman yang kesusahan.

Menurut Beaty dalam Susanto (2011:137), menyatakan bahwa perkembangan sosial anak berkaitan dengan perilaku prososial dan bermain sosialnya. Aspek perilaku sosial meliputi :

a. Empati, yaitu menunjukkan perhatian kepada orang lain yang kesusahan atau menceritakan perasaan orang lain yang mengalami konflik.

b. Kemurahan Hati, yaitu berbagi sesuatu dengan yang lain atau memberikan barang miliknya.

c. Kerja Sama, yaitu bergantian menggunakan barang, melakukan sesuatu dengan gembira.

d. Kepedulian, yaitu membantu orang lain yang sedang membutuhkan bantuan. 
Website : http://sosial.unmermadiun.ac.id/index.php/sosial

Mengingat pentingnya interaksi teman sebaya terhadap perkembangan perilaku sosial anak di RA Muslimat NU 007 Gandu 1 Mlarak Ponorogo, maka guru memiliki beberapa cara untuk meningkatkan interaksi positif antar teman sebaya di sekolah tersebut. Beberapa upaya yang telah dilakukan guru dalam hal tersebut antara lain: dengan mengadakan permainan jala ikan. Dalam permainan ini anak mendapatkan satu pembelajaran pentingnya beriteraksi dan bekerja sama dalam kelompok.

Dengan demikian dapat disimpulkan bahwa manfaat interaksi teman sebaya terhadap perilaku sosial anak usia dini di RA Muslimat NU 007 Gandu 1 Mlarak Ponorogo antara lain memberikan dukungan social, moral, dan emosional, anak dapat belajar untuk saling menghargai orang lain, memiliki sikap tanggung jawab, belajar bekerja sama, saling berbagi dan peduli terhadap kondisi teman yang lain. Mereka belajar untuk berempati dan mulai belajar membantu teman yang kesusahan.

\section{KESIMPULAN}

Berdasarkan rumusan masalah dan hasil penelitian dapat disimpulkan bahwa:

1. Perilaku sosial anak usia dini di RA Muslimat NU 007 Gandu 1 Mlarak Ponorogo berkembang baik yang dapat dibuktikan dengan adanya sikap saling menolong, saling menghargai, saling bekerja sama, mampu membedakan yang baik dan buruk serta mampu bersikap sopan santun.

2. Interaksi teman sebaya di RA Muslimat NU 007 Gandu 1 Mlarak Ponorogo berkembang dengan baik, anak sudah mampu berinteraksi dengan baik, bersahabat dan bermain bersama temannya, meski ada salah satu anak yang kurang dalam interaksinya namun kini sudah mulai berkembang berkat berbagai pendekatan yang dilakukan oleh guru.

3. Manfaat interaksi teman sebaya terhadap perilaku sosial anak usia dini di RA Muslimat NU 007 Gandu 1 Mlarak Ponorogo antara lain memberikan dukungan social, moral, dan emosional, anak dapat belajar untuk saling menghargai orang lain, memiliki sikap tanggung jawab, belajar bekerja sama, saling berbagi dan peduli terhadap kondisi teman yang lain. Mereka belajar untuk berempati dan mulai belajar membantu teman yang kesusahan.

\section{VI.DAFTAR PUSTAKA}

Aden, R. 2011. Serba-Serbi Pendidikan Anak. Yogyakarta: SIKLUS

Ahmad Susanto. 2011. Perkembangan Anak Usia Dini. Jakarta: Prenada Media Group

Mu'tadin, Z. 2002. Pengantar Pendidikan dan Ilmu Perilaku Kesehatan. Yogyakarta. Andi Offset

Muhammad, F. 2012. Desain Pembelajaran PAUD. Yogyakarta. AR-RUZZ Media

Regina. 2015. Hubungan Interaksi Sosial Teman Sebaya Dengan Perilaku Sosial Anak Di Pendidikan Anak Usia Dini Sentosa Pontianak Kota. Jurnal online. http://repository.unmuhpnk.ac.id/103/1/JURNAL\%20REGINA.pdf. Diakses April 2018

Samsunuwiyati, Mar'at. 2005. Psikologi Perkembangan. Bandung: PT.Remaja Rosda Karya

Sanan dan Yamin. 2013. Panduan PAUD. Ciputat: Gaung Persada Press Group

Santrock, J.W. 2007. Perkembangan Anak. Jakarta: PT Erlangga

2002. Perkembangan Masa Hidup. Jakarta : Erlangga

Sugiyono. 2015. Metode Penelitian Pendidikan Pendekatan Kuantitatif, Kualitatif dan R\&D. Bandung: Alfabeta

Suyadi. 2010. Psikologi Belajar PAUD. Yogyakarta: Pedagogia

Yanita \& Zamralita. 2001. Persepsi Perempuan Primipara tentang Dukungan Suami dalam Usaha Menanggulangi Gejala Depresi Pasca Salin. Phronesis. Vol: 3. No: 5. h: 4 